\title{
Comparison of Issues and Countermeasures among Previous and Current Squatter Formations in Yangon, Myanmar
}

\author{
Myint Naing ${ }^{*}$, Vilas Nitivattananon ${ }^{2}$ \\ ${ }^{1}$ Department of Urban and Housing Development, Ministry of Construction, Nay Pyi Taw, Myanmar \\ ${ }^{2}$ Urban Environmental Management Program, School of Environment, Resources and Development, Asian Institute of Technology, \\ Bangkok, Thailand \\ Email: *myintnaing.duhd@gmail.com
}

How to cite this paper: Naing, M., \& Nitivattananon, V. (2020). Comparison of Issues and Countermeasures among Previous and Current Squatter Formations in Yangon, Myanmar. Current Urban Studies, 8, 396-416.

https://doi.org/10.4236/cus.2020.83022

Received: June 25, 2020

Accepted: August 30, 2020

Published: September 2, 2020

Copyright $\odot 2020$ by author(s) and Scientific Research Publishing Inc. This work is licensed under the Creative Commons Attribution International License (CC BY 4.0).

http://creativecommons.org/licenses/by/4.0/

\begin{abstract}
Along with the transition era, Yangon has been facing rapid urbanization and being challenged by the inevitable urban issues including slum and squatter settlements. Current squatter formation and expansion has been emerging in Yangon with the dichotomy between the urban population growth and the urban poverty. In this study, the main objective is to compare the root causes and countermeasures between the current and previous squatter formations. Mixed research, including qualitative and quantitative approaches, is applied to analyze data obtained from both primary and secondary sources. This paper argues that although the participatory approach is the most effective practice in the developing countries, the community-led housing scheme is doubtful for success in Yangon context. The major concerns regarding government role and will or mind-set of governmental organizations, paternalistic role of professionals, selective participation and excessive pressure for immediate results have been reported. It recommends that slum upgrading schemes should focus both on physical infrastructures and socio-economic development.
\end{abstract}

\section{Keywords}

Countermeasures, Participatory Approach, Rapid Urbanization, Squatter Formation, Yangon

\section{Introduction}

The Inevitable consequence of urbanization, the squatter, a kind of slum, can be seen all over the developing countries such as Myanmar (Abu-Salia, Osumanu, 
\& Ahmed, 2015). While many governments accept slum upgrading as primary global agenda in MDG (2000-2015) and SDG (2015-2030), the actual number of slum population increased from 807 million to 883 million during 2000-2015 (HLPF, 2018).

Likewise, under the transition era of Myanmar, squatter formation in Yangon which is a noticeable urban agenda and nearly half million of squatter population is currently registered. It is the fourth remarkable squatter formation, and the most tremendous formation which can be compared about 200 thousands population as second squatter formation in 1950s and about 250 thousands population as third squatter formation in 1980s.

Although the first squatter formation under British ruling was solved without particular countermeasure, countermeasures from second and third squatter formations were mainly applied resettlement by force eviction to new satellite towns. Community-based practice or participatory slum improvement is the best current practice on the third world, but it was never applied in Myanmar until 2000s.

The main objectives of this study are to compare the root causes and countermeasures between the current and the previous squatter formations, and on the practicability of participatory approach as community-led housing projects by Yangon Region Government in relation to the experience from selected countries in Asia. This study was scoped on urban squatter issues of Yangon being the most populous and business city, as former capital of Myanmar.

\section{Literature Review}

"Cities without Slum", the popular wording among urban thematic, that is very beautiful and meaningful but it is very challenging for the third world (Gilbert, 2007). Slum is generally a heavily populated urban informal settlement characterized by substandard housing and squalor (UN-Habitat, 2003). Nowadays, slum and squatter have been becoming an integral part of urban landscape especially prime city of the developing countries such as Myanmar (Malik, Roosli, \& Tariq, 2020). Moreover, slum upgrading is globally accepted as one of the priorities of sustainable development (Meredith \& MacDonald, 2017).

\subsection{Evaluation of Slum Upgrading Policies}

Slum and squatter formations are chronic phenomena at the prime cities in the third world (Menshawy, Shafik, \& Khedr, 2016). Slum formation is commonly rooted in industrialization, rural-urban migration, economic stagnation and depression, high unemployment, poverty, informal economy, poor planning, natural and man-made disasters, and social conflicts. Rapid urban population growth and increase of urban poverty are posing unprecedented problems and governments from the developing countries must undertake to overcome and/or ease for slum agenda for the sustainable development (Johar, 2017; Meredith \& MacDonald, 2017). 
During the $20^{\text {th }}$ Century, slum upgrading policies have been gradually evolved four phases in line with the National Housing Policies (NHP) as Public Housing (1950-1972), Self-Help (1972-1988), Enablement (1986-1992) and National Slum Upgrading Programme, the Cities Alliance (current) (Andavarapu \& Edelman, 2013; Nazire, Kita, Okyere, \& Matsubara, 2016). It can be stated in Figure 1.

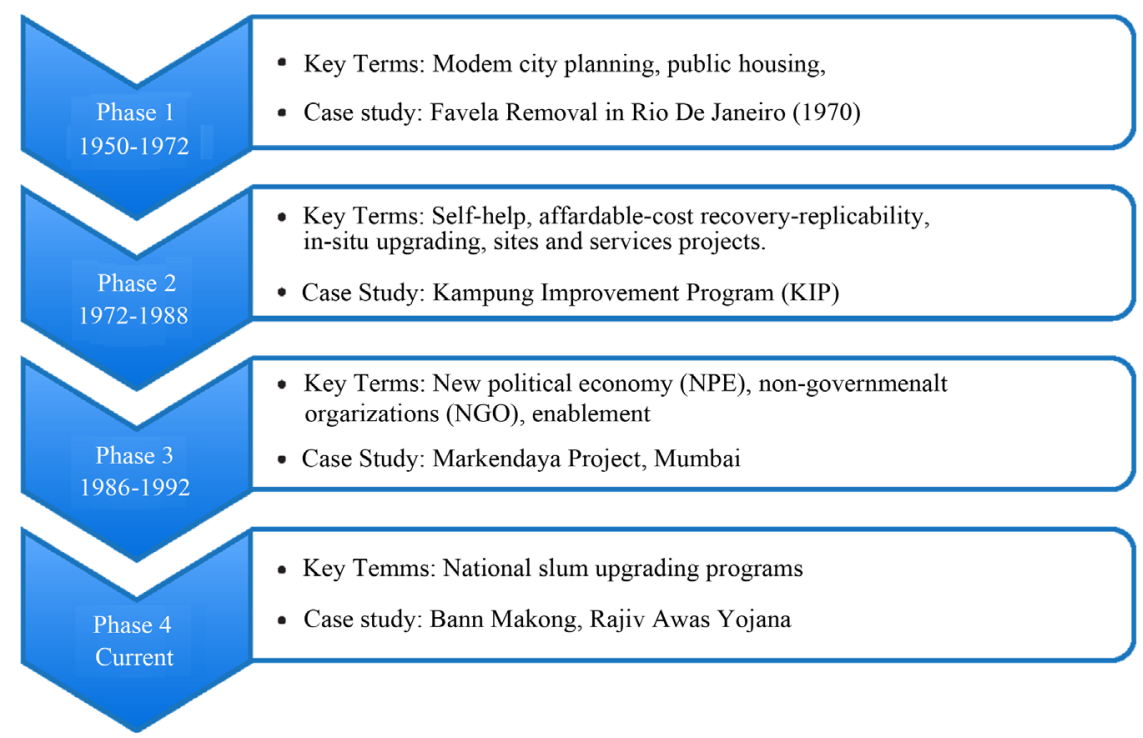

Figure 1. Phases of slum redevelopment policy. Source: (Andavarapu \& Edelman, 2013).

According to the awareness of global community, slum upgrading is one of the prioritized global agendas, and UN officially declared Goal 7: Target 7D in Millennium Development Goals (MDGs) and Goal 11 in Sustainable Development Goals (SDGs). UN-Habitat generally categorized six slum policy instruments as Negligence, Eviction, Self-help and in situ upgrading, Enabling policies, and Resettlement and Participatory slum improvement. Based on the long experiences from Latin American and Caribbean Region (LAC); slum upgrading policies are roughly based on three forms of intervention such as direct provision of government-led and subsidized social housing, market-based and demand-side subsidies, and slum clearance and upgrading. In the 1980s, majority of governments have withdrawn from housing provider and shifted to facilitator on the private sector's efforts to supply affordable housing (Magalhaes, 2016).

LAC region experiences mentioned that policy instruments should be in accordance with the fundamentals as from government-led to market-based housing programs; from mass public housing to a twin-track approach; and learning from the bottom up (Magalhaes, 2016). Among these policy instruments, experts from UN-Habitat mentioned Participatory approach is the best current practice because it is focused not only on housing and basic infrastructures but also social and economic sustainability. They recommended that these development goals related slums have catalyzed the promotion of integrated approaches by all stakeholders. The detail recommendations can be as stated in Figure 2. 


\begin{tabular}{ll}
\hline Do & Don't \\
\hline Promote good urban governance systems. & Assume that slums will disappear automatically with economic growth. \\
\hline Establish enabling institutional frameworks involving all partners. & Underestimate the role of local authorities, landowners, community \\
\hline & lenders and residents. \\
\hline Implement and monitor pro-poor city development strategies. & Separate upgrading from investment planning and urban management. \\
\hline Encourage initiatives of slum dwellers and recognize the role of women. & Ignore the specific needs and contributions of women and vulnerable groups. \\
\hline Ensure secure tenure, consolidate occupancy rights ard regularize informal settlements. & Carry out unlawful forced evictions. \\
\hline Involve tenants and owners in finding solutions that prioritize collective interests. & Discriminate against rental housing or promote a single tenure option. \\
\hline Adopt an incremental approach to upgrading & Impose unrealistic standards and regulations. \\
\hline Associate municipal finance,cross-subsidies and beneficiary contributions to ensure & Rely on governmental subsidies or on full-cost recovery from slum dwellers. \\
\hline financial viability. & \\
\hline Design and negotiate relocation plans only when absolutely necessary. & Invest publie resources in massive social housing schemes. \\
\hline Combine slum upgrading with employment generation and local economic development. & Consider slum upgrading solely as a social issue. \\
\hline Develop new urban areas by making land and trunk infrastructure available. & Provide uraffordable infrastructure and services. \\
\hline
\end{tabular}

Figure 2. The “dos” and “don'ts” of slum upgrading. Source: (UN-Habitat, 2003).

\subsection{Participatory Slum Improvement: Effectiveness Approach for Integration}

Participatory slum improvement or Community upgrading is an effective instrument for the third world in the late $20^{\text {th }}$ Century (Croese, Cirolia, \& Graham, 2016). All strategies including community upgrading need to be linked not only upgrading of housing and physical infrastructures but also social services, the delivery of tenure, and the improvement in the economic circumstance of the urban poor (Van Horen, 2004). Key philosophy in urban slum upgrading is to harness the holistic and integrated uplifting on the social, economic and physical potentials of these communities as integral part of the urban society and the wider urban fabric (APMCHUD, 2010). Holistic concepts and elements of community development can be seen as in Figure 3.

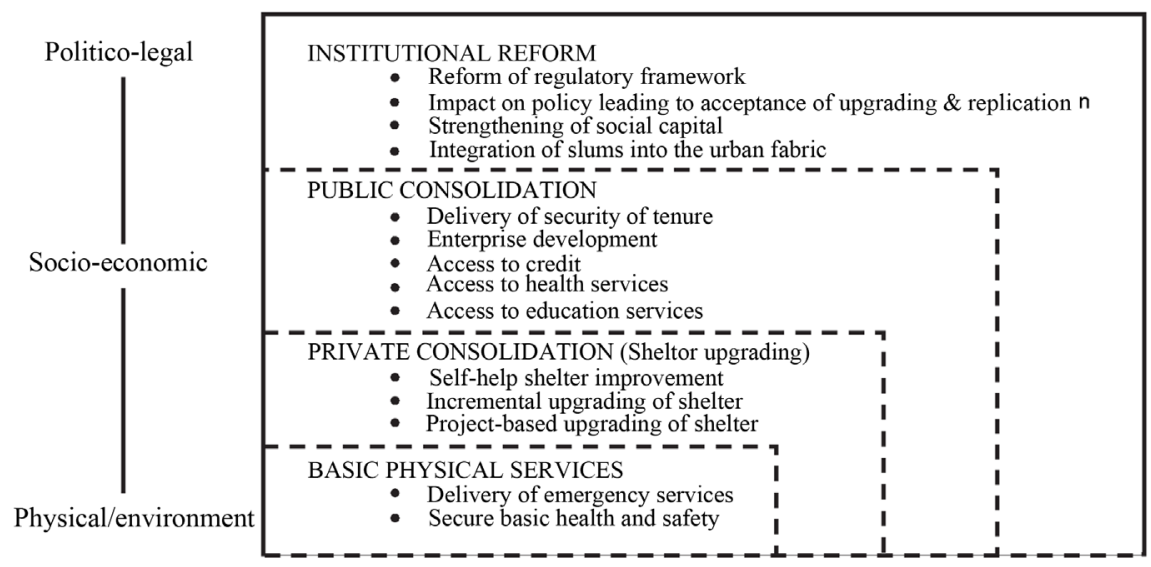

Figure 3. Holistic concepts and elements of community development. Source: (Van Horen, 2004).

However, previous experiences show that significant weaknesses are inhibiting the scaling up of upgrading and the extent on longer-term for sustainability. In short-term, the function of poor project design and the function of weak governance institutions are also failed factors for practicing (Andavarapu \& Edelman, 2013). Sometimes, policies and practices for slum upgrading can- 
not integrate strongly into the urban fabric and far as a separate part of cities. In recent years, UN-Habitat has mentioned that previous enabling policies could not get effective results on housing challenge and governments should reconsider on the leadership role in housing provision (Croese, Cirolia, \& Graham, 2016).

Similarly, Botes \& Van Rensburg (2000) explored nine impediments for community participation development as a metaphor for the nine plagues (Botes \& Van Rensburg, 2000). There are; 1) the paternalistic role of development professionals; 2) the inhibiting and prescriptive role of the state; 3) the over-reporting of development successes; 4) selective participation; 5) hard-issue bias; 6) conflicting interest group with end-beneficiary communities; 7) gate-keeping by local elites; 8) excessive pressure for immediate results" the accentuation of product at the expense of process and 9) the lack of public interest in becoming involved.

\subsection{Selected Slum Upgrading Programs from Asian Countries}

Nowadays, facts related to urbanization of Asia are very significant and $60 \%$ of the increase of world urban population will emerge in Asian Cities. With rapid urbanization, the dichotomy of prominent impacts can be incurred together the economic development of cities and the increase of urban poverty (Majale, 2008). Roundabout one billion people or one-third of the urban population is estimated to be residing in urban slum areas and nearly $60 \%$ or 554 million slum dwellers are in Asia (Ooi \& Phua, 2007).

\subsubsection{Comprehensive Kampong Improvement Program (C-KIP) from Indonesia}

Comprehensive Kampong Improvement Program (C-KIP) had been famous slum upgrading from Indonesia. Slum upgrading in Indonesia has a long story and it was one of the key parts of every National Development Plan (Repelita) since the 1960s (Das, 2015). There are three generations was evolved which based on lesson learning from previous programs (Tunas \& Peresthu, 2010).

The Kampong Improvement Program (KIP) (called the world's first slum upgrading program) was initiated in Jakarta in 1969 which focused on only physical conditions as providing basic infrastructure and upgrading housing. The second generation approaches attempted to integrate physical, social and economic improvements during the late 1980s and early 1990s. After the Asian Financial Crisis of 1997, the government has driven to enhance to the third generation for integrating and incorporating on physical, social and economic improvements, and livelihood enhancements (Minnery, Argo, Winarso, Hau, Veneracion, Forbes, \& Childs, 2013).

Main objectives of C-KIP are to improve the living environment and quality of life of urban poor; to expand the productive capacity of the residents; to benefit as many of the poorer people in the shortest period; to minimize disruption of their socio-economic lives; to mobilize their potential for self-help and commu- 
nity cooperation.

\subsubsection{The Million Houses Program (MHP) from Sri Lanka}

The Million Houses Program (MHP) had the great success in the 1980s in Sri Lanka and it became a leading lesson for other developing countries. Sri Lanka is globally well known for achieving high levels of human development at relatively low levels of GDP per capita that are comparable to industrial countries (Tudawe, 2001). Government strong will is the most successful factor for achievement on social welfare programs.

MHP: named as aided self-help approach, tried to assist poor households gaining access to housing, started with beneficiaries putting-in their own labour to reduce the overall cost of land development and/or house construction, to provide serviced plots with or without core-housing to enable incremental construction (Joshi \& Khan, 2010). Besides, “building material banks" could provide housing materials (often for recycled materials), small housing loans and technical support for housing construction.

The famous comprehensive program for upgrading informal settlements and enabling access to basic services was led by local communities (self-help groups) called by "Community Development Councils" (CDCs) with support by UNICEF. Similarly, participatory approach (Bottom-up Approach) was mainly applied in this program such as "Community Action Planning" (CAP). "Learning by Doing and Doing by Learning" was centrally concept of the MHP (Joshi \& Khan, 2010).

\subsubsection{Baan Mankong Program (BMK) from Thailand}

Baan Mankong Program (Secure Tenure Program) (BMK) was under leapfrog progress in housing policy and program which were launched by the Thai Rak Thai Party in Thailand. 10 pilot slum upgrading projects were approved in 2003 under this program and extended to a target of upgrading the housing and living environment of 300,000 households of poor communities across the whole country. This program has received praise for its innovative participatory approaches with the target "City Without Slum" within five years across Thailand (Archer, 2012).

The key player in the exercising on BMK is the Community Organizations Development Institute (CODI), the public organization which was founded in the 1980s with a special purpose for informal settlements (Dhabhalabutr, 2016). Its innovative approach has been derived from collective experiences over the past twenty years as lessons, experiences, knowledge and development in the housing problem solving of the slum people especially emphasizing on the participation of the poor in developing their own residences and communities. According to this approach, the role of slum dwellers would be changed from " $\mathrm{Be}$ neficiaries" or "Support receivers" to "Project owners".

There is no fixed model for housing development and tools depend on the community's requirements based on problem, affordability, conditions and 
needs. At the same time, BMK has tried to solve community development issues with brainstorming and planning as an environment or neighbourhood development. One of the notable concepts of BMK is to solve problems of the whole city instead of solving the problem of a particular community. The significant difference of MBK that is the strategy of collective land tenure has been adopted to ensure that poor people sustain themselves as a community rather than selling up and squat again which was a common phenomenon of previous unsuccessful schemes.

\section{Methodology}

Mixed research design has been mainly applied in this study, utilizing both primary and secondary sources of data collection, with qualitative and quantitative techniques for data analysis. Root causes and countermeasures between current and previous squatter formations are compared through a combination of secondary sources such as literature reviews from historical documents, and from documents of concerned departments mainly General Administration (GAD) and Department of Urban and Housing Development (DUHD).

Participatory approach for the lessons learnt from selected Asian countries and the current Yangon squatter context is also studied through a mixed approach with literature reviews and primary data (as details in Section 3.2). Qualitative data analysis is applied throughout the outcomes of a KII (Key Informant Interview) and two FGDs (Focus Group Discussions). As a quantitative approach, Likert scale analysis is mainly applied through the outcomes of questionnaire survey.

\subsection{Study Area}

Yangon, the research area, is situated on the part of Irrawaddy delta forming the main arterial river for Myanmar civilizations (Kyaing, 2014). Currently, Yangon is a business capital of Myanmar with total area of 1068 square kilometer and population of over 8 million, which makes up $15 \%$ of the total population and one third of the urban population in Myanmar. According to the squatter registration by Yangon Region Government in July, 2017, 155,594 households were registered as squatter residents and total population can be counted as 475,031 (YRG, 2017). Among them, majority of squatter pockets are erected on new satellite towns which are built in 1990s under Military Ruling. Location map for current informal settlements in Yangon can be seen in Figure 4.

\subsection{Data Collection and Analysis}

The collection of data can be divided into the secondary data as literature reviews, reports and documents from concerned organizations, and the primary data from Key Informant Interview (KII), Focus Group Discussion (FGD) and the questionnaire survey. Data for previous countermeasures of squatter agenda and current squatter situation are examined through the methods of historical reviews, 


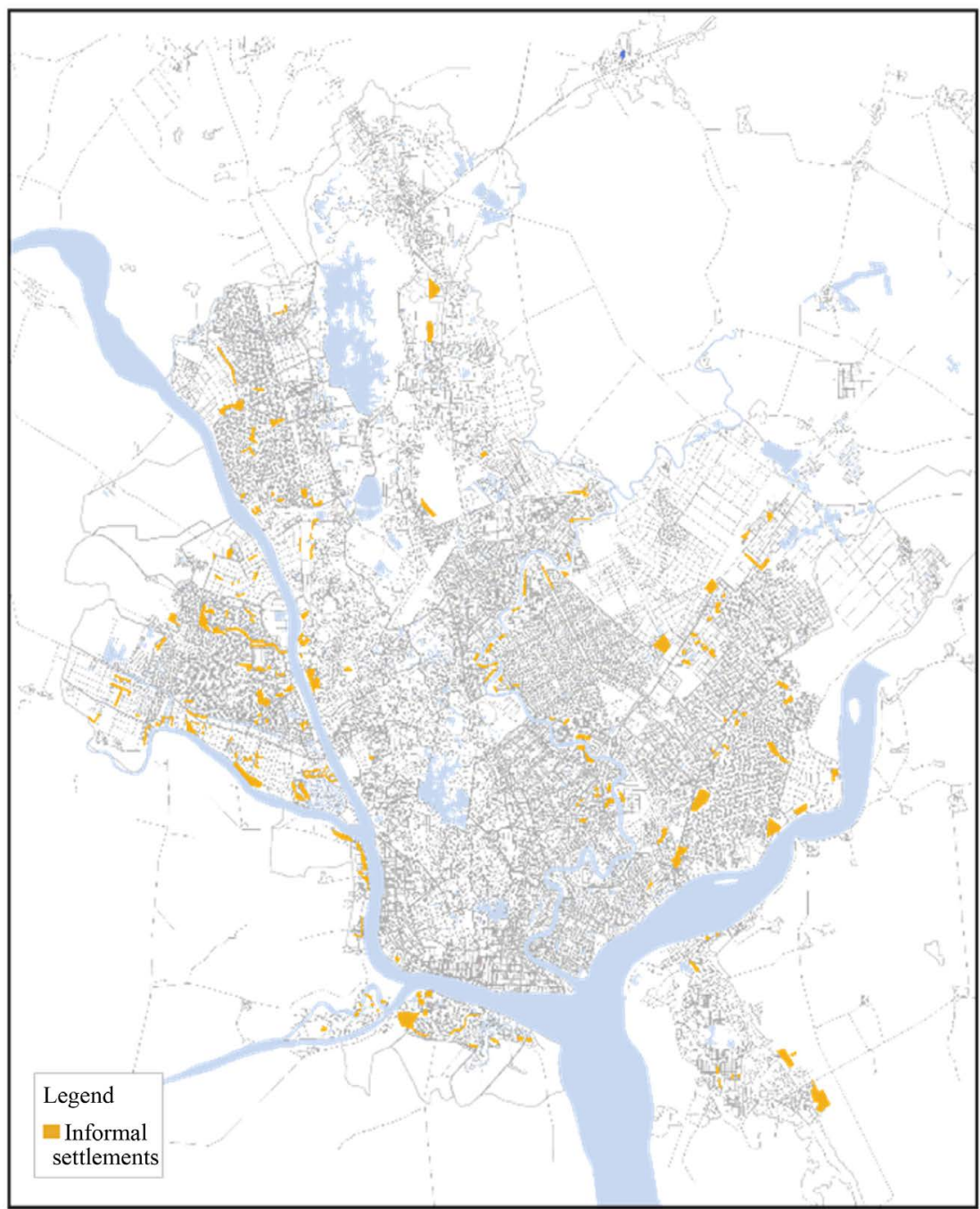

Figure 4. Map of Informal Settlement in Yangon (2019). Source: (UN-Habitat-Myanmar, 2019).

literature reviews, and collection from related organizations mainly GAD and DUHD. The lessons learned from the participatory approach of selected Asian countries and the current squatter formation is mainly compared and analyzed on primary data with qualitative approach. KII with expert groups and Focus Group Discussions (FGD) with community leaders and survey questionnaire with all stakeholders were also conducted.

Six interviewees were part of the KIIs, three of them are experienced senior officials from DUHD and three are top level managers from NGOs. Major topics of KI are countermeasures for previous squatter formation (especially 1950s and 1990s), merits and demerits of these countermeasures and opinions on participatory approach. 12 community leaders are conducted as interviewees for FGDs. FGD results are mainly divided into root courses of migration, general socio-economic of squatter dwellers and sentiment of participatory approach in Yangon context. 
Sixty samples from multi-stakeholders as parliament members, government officials, housing experts from academia, and managers from NGO and leaders from squatter community were involved in the questionnaire survey. Survey questionnaire can be mainly divided into three parts as root causes of squatter formation, expectation on countermeasures, and sentiment on community-led housing project as with participatory approach as newest countermeasure in Myanmar.

Data analysis is a mixed method with qualitative and quantitative techniques. The narrative qualitative analysis through KIIs and FGDs was applied to find out root causes and countermeasures of previous and current slum formation. Sentiment of squatter household and practicability of community-led housing programme were explored from FDGs and survey result. For quantitative analysis, Likert scale data analysis is mainly applied for key finding that participatory approach is practicable for squatter clearance for Yangon context.

\section{Previous Remarkable Squatter Formations in Yangon}

The British constructed Yangon in 1852 after the Second Anglo-Burmese War. Although the fundamental intention was the erection of the port for colonializing on Burma (Old-name of Myanmar) and it had gradually grown and expanded as the capital of Myanmar until 2005. Under the British Ruling; Myanmar that hitherto remote and the little known country became rapidly the biggest exporter in the world of rice and hardwood teak by its plenty of natural resources during the 1870 s to 1930 s. There were many reasons based for increasing export orientation of Myanmar that era; important facts were as opening of Suez Canal in 1869 could promote for maritime trade between Europe and Asia; the American Civil War (1861-1865) destroyed the rice exports from North and South Carolina to Europe; the Indian Mutiny (late of the 1850s) also disrupted the flow of rice from India; and introduction of famous and amazing quality of Myanmar teak (Maung, 1963).

\subsection{First Squatter Formation}

The earliest and the first urban squatter formation of Yangon could be seen under that Colonial Era at the end of the $19^{\text {th }}$ century. In that time, historians labeled Yangon as "Rangoon was a foreign city erected on Burmese soil" with foreign immigrants especially Indian as imported labour forces. British imported the floods of India immigrant labour not only production field of rice, teak and other extracting industries but also urban industries and services. During those periods, the population growth rate was very rapid from 92 thousand in 1872 to 400 thousand in 1931. At the same time, the Indian population ratio was also a rapid increase to $53 \%$ as 213 thousand in 1931 (Kyaw, 1971). Comparison between Indian and other ethnic groups under British Ruling can be stated in $\mathrm{Ta}$ ble 1. 
Table 1. Population comparison between citizen and foreigners in Yangon under British ruling.

\begin{tabular}{ccccccc}
\hline Year & $\begin{array}{c}\text { Myanmar } \\
\text { Nationalities }\end{array}$ & Indian & Chinese & European & Others & Total \\
\hline 1872 & 69,306 & 15,677 & 3181 & 3867 & 270 & 92,301 \\
1881 & 67,019 & 66,007 & 3752 & 4343 & 227 & 141,438 \\
1891 & 73,306 & 87,487 & 7576 & 7831 & 383 & 176,583 \\
1901 & 81,686 & 119,290 & 11,016 & 8479 & 966 & 221,437 \\
1911 & 90,793 & 172,978 & 16,055 & 11,563 & 1487 & 292,876 \\
1921 & 114,870 & 189,435 & 23,819 & 12,290 & 1569 & 341,983 \\
1931 & 140,141 & 212,929 & 30,626 & 14,404 & 2315 & 400,415 \\
\hline
\end{tabular}

Source: (Kyaw, 1971).

First squatter formation could be found East part of Yangon near the East Theinbyu especially along the railway track; between Royal Lake and railway track; and squatter dwellers were Indian migrants who provided for urban services as mostly washer-men and non-skill workers. Some Burmese squatter pockets situated Western areas of Yangon near Kyeemyindaing and Sanchaung villages.

Under the British colony, particular policy or countermeasure for slum and squatter issues could not be found but some actions has directly impact on benefits of squatter dwellers such as recognizing the squatter dwellers by collection of the small amount as squatter fee, and facilitated and promoted the private rental housing as terraces by Indian, Chinese and Myanmar landlords (RDT, 1941). Furthermore, British rulers wanted to ignore about squatters because they provided essential lower-level services for European elites.

\subsection{Second Squatter Formation}

The main cause of second major squatter formation was rooted in the impact of wars such as the Second World War (WWII) and the Civil War between government and various rebel groups (called colourful rebels) with many reasons especially ethnics and ideology conflicts. During WWII, Yangon was heavily destroyed by bombing both side of Japanese and British air forces and resulted in the immense housing shortage. At the same time, Yangon stroked by rapid rural-urban migration with impact of the civil war. Yangon population was rapidly increased in double at before and after WWII as half million to one million. During 1959s, 56 listed squatter wards on government land were recorded by Yangon Municipality and about two hundred thousand population lived at those wards (GAD, 1982).

During 1958, the military had seized national power and founded as "Home Taker Government". They assigned Colonel Htun Sein as the Mayor of Yangon and his major task was uplift of municipal duties as clean and beautiful of Yan- 
gon. With his famous motto "Wash the city with sweat", Yangon Municipality had its activities very well on both municipal services and squatter clearance. The government built three new towns which are Thaketa, North Okkalapa, South Okkalapa and the provided seventy thousand land plots. The government provided and resettled totally 32,866 plots with urban services for squatters (in detail; 9226 plots in Thaketa, 11,923 plots in North Okkalapa and 11,717 plots in South Okkalapa) (HD, 1987). Although Public accepted the effort of Yangon Municipality for urban development in Yangon, squatter resettlement scheme was as forced eviction by the military government. Historical photos of squatter clearance can be seen in Figure 5.

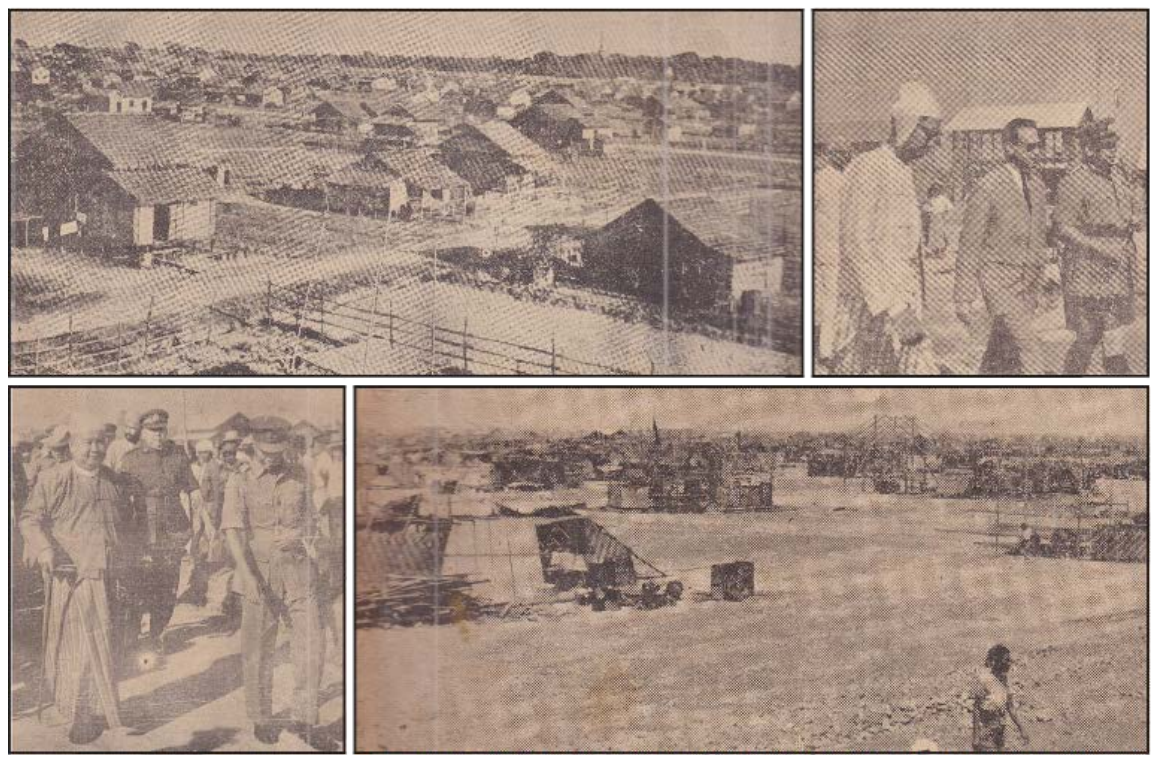

Figure 5. Historical Photos for Squatter Clearance in 1950s. Clockwise from Top-Left: 1) View on South-Okkalapa (1959); 2) Site Visit of UN Secretary General Desh Hammarskjold; 3) View on Thaketa (1959); 4) Site Visit of Prime Minister U Nu. Source: (DUHD Library from Newspapers, 1959).

\subsection{Third Squatter Formation}

Population growth and industrialization were root causes of third squatter formation under socialism regime during the 1960s to 1980s. The natural growth of population in the rural area was kicked out as the labour force to urban areas. Besides, industrialization was gradually introduced in Myanmar and the socialist government tried to build various factories all over the country especially in Yangon. Therefore, the third slum formation was a different circumstance from previous formations as pulling by socio-economic intention (HD, 1987).

The Housing Corporation had tried to focus and provide the squatter clearance schemes those were the relocation in new towns and upgrading the squatter wards as land readjustment. But, those schemes were not scaled up because the Socialist Government wanted to neglect for propaganda. Only 9290 households for relocation and four wards for upgrading were tackled during that period. 
According to the reports of DHSHD, amount of 66,162 households and 259,237 squatter populations could be counted at 26 townships in Yangon in 1988 (HD, 1987).

After the collapse of Socialism in 1988, Military Government built six new satellite towns for Yangon expansion and they moved the majority of squatters to these new towns by force under the resettlement programme. Another squatter clearance scheme as "Hut to Apartment"; which was one of the success stories among past squatter experiences under Military Government. That programme was implemented with the models of China from 1993 to 1998. That scheme was the new concept as the combination of onsite upgrading and urban land readjustment. Most of the proposed locations were strategic and prime for commercial viability to private sector investment.

Under these schemes, the government implemented many locations and resettled as 34 projects of hut to apartment which could provide 6654 apartments for slum dwellers (Moe, 2013). Reasons for the success of this scheme were the satisfaction of all parties as aesthetic of city; meet to the government will; substantial benefit for private sector; and acceptance of slum dwellers. That schemes were successful with acceptance of all stakeholders, notwithstanding that it was stopped at the end of the 1990s with various reasons as the impact of 1997-1998 South East Asia Financial Crisis; the decrease of government political will; shortage of suitable location; and corruption and fraud among the implementers.

\section{Current Squatter Formation}

Under the dramatic transition era of Myanmar since 2011, internal migration of Yangon has been rapidly increasing with the development of socio-economic sectors. In the last decade, national economic pattern has been changed significantly as a shift away from agro-based economy to industrial and services based economy. In 2014-2015 proportion of agriculture sector accounted 27.9\% GDP, industry $34.4 \%$ and services $37.7 \%$ which can be compared with the share of agriculture of $36.8 \%$ in 2010-2011 (CSO, 2015).

Majority of squatter population are internal migrants from rural and small towns with socio-economic reasons such as job opportunity and better quality of life. Moreover, other noticeable push factors have been fueled on internal migration as natural disasters and insurgency from remote areas especially ethnical regions. Cyclone Nagis (2008), Myanmar Floods (2015), 2010s ethnical crisis in Rakhine (Bangladesh-Myanmar Border), and insurgency of North-East Conflict between Myanmar army \& minor ethnic armed groups which are significant example of driving forces for floods of migrant to urban areas especially Yangon.

According to the 2014 census, one fifth of the population are lifetime migrants and a total of 3.35 million were recent migrants who having moved in the five years preceding the census (DoP, 2015). Final destination of internal migrants is Yangon city and it can be seen in Figure 6. 


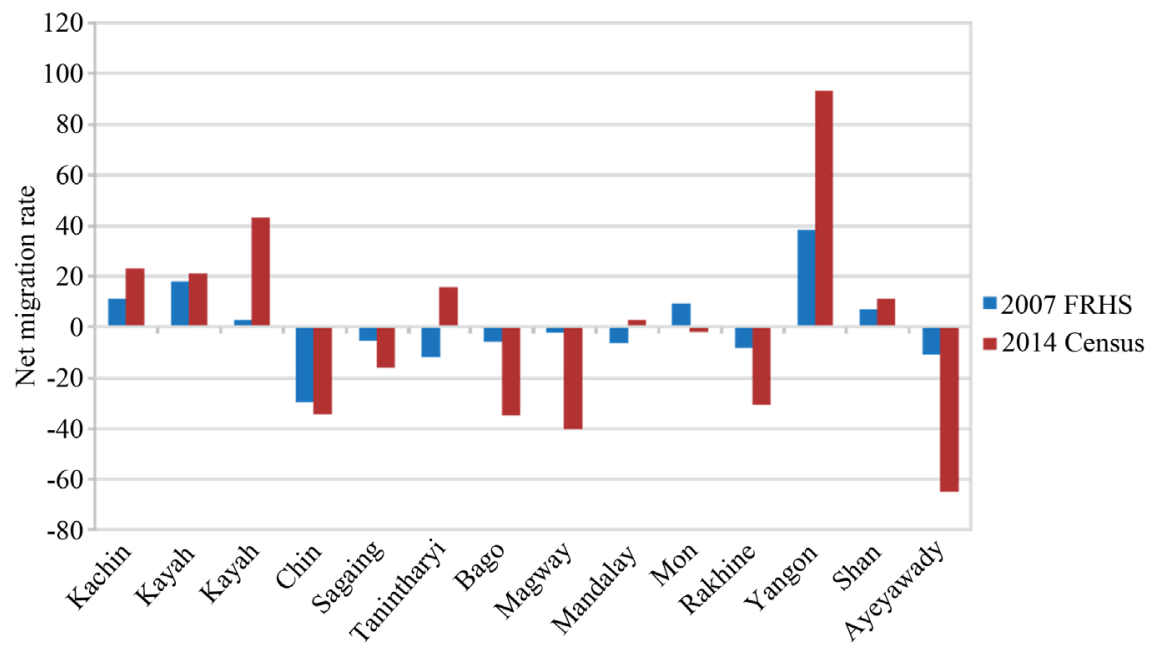

Figure 6. Net migration rate for inter regions and state (2014). Source: (DoP, 2016).

\subsection{Registration on Current Squatter Formation}

Current government led by National League for Democracy (2016-2021) primarily Yangon Region Government (YRG) has recognized and started to tackle on the current squatter formation as the important urban agenda in Yangon since 2016. Generally, they set up into three phases for handling on squatter formation as Registration, Screening \& Classification, and Countermeasures of slum formation. Scheme for squatter registration had exercised on the whole Yangon during September, 2016 to July, 2017. This scheme had been divided into 3 stages on 45 townships as 1 township (pilot project), 12 townships and 32 townships (YRG, 2017).

According to their report, 8 townships have no squatters and 37 townships have squatter pockets among 45 townships. Hlinethaya has the most squatter populations as 120,736 and 13 townships have accepted over ten thousand squatter populations. Majority of squatter pockets are situated in the six new satellite towns (erected in 1990s) and urban fringe of Yangon city. Registered squatter population by townships can be seen in Table 2 .

Table 2. Squatter Population by Township (July, 2017).

\begin{tabular}{lccccccc}
\hline No & Township & \multicolumn{2}{c}{ Household Population } & No & Township & Household Population \\
\hline $\mathbf{1}$ & Dagon Myothit (North) & 3754 & 12,327 & $\mathbf{2 0}$ & Hline & 580 & 2031 \\
$\mathbf{2}$ & Dagon Myohit (Seikkan) & 17,136 & 52,708 & $\mathbf{2 1}$ & Bahan & 126 & 321 \\
$\mathbf{3}$ & Dagon Myothit (South) & 5665 & 22,488 & $\mathbf{2 2}$ & Kyauktan & 3929 & 11,598 \\
$\mathbf{4}$ & Dagon Myothit (East) & 6901 & 22,468 & $\mathbf{2 3}$ & Dala & 10,618 & 33,630 \\
$\mathbf{5}$ & Thakayta & 1569 & 5308 & $\mathbf{2 4}$ & Thanlyin & 8932 & 25,290 \\
$\mathbf{6}$ & Okkalapa (North) & 10,789 & 36,045 & $\mathbf{2 5}$ & Thongwa & 597 & 1161 \\
$\mathbf{7}$ & Pazuntaung & 117 & $\mathbf{3 0 8}$ & $\mathbf{2 6}$ & Khayan & 2035 & 4128 \\
$\mathbf{8}$ & Botahtaung & 131 & 466 & $\mathbf{2 7}$ & Kungyangon & 1338 & 3607 \\
$\mathbf{9}$ & MingalaTaungnyunt & 507 & 1718 & $\mathbf{2 8}$ & Twantay & 430 & 1389 \\
\hline
\end{tabular}




\begin{tabular}{lccccccc}
\multicolumn{2}{l}{ Continued } & \multicolumn{7}{l}{} \\
\hline 10 & Thingangyun & 1353 & 4385 & 29 & Kawhmu & 892 & 2598 \\
11 & Yankin & 552 & 1890 & 30 & Shwepyitha & 11,967 & 35,163 \\
12 & Dawbon & 487 & 1842 & 31 & Hlinethaya & 38,316 & 120,736 \\
13 & Okkalapa (South) & 1825 & 6177 & 32 & Insein & 4703 & 14,201 \\
14 & Ahlon & 403 & 1315 & 33 & Taikkyi & 107 & 269 \\
15 & Mayangon & 278 & 946 & 34 & Mingaladon & 6287 & 16,857 \\
16 & Kyimyindine & 18 & 60 & 35 & Htantabin & 1561 & 3093 \\
17 & Kamayut & 14 & 61 & 36 & Hmawbi & 2812 & 7856 \\
18 & Dagon & - & - & 37 & Hlegu & 8864 & 19,589 \\
19 & Lanmadaw & 1 & 2 & & Total & 155,594 & 475,031 \\
\hline
\end{tabular}

Source: (YRG, 2017).

During the registration process, although collecting teams had tried to cover all squatter population, they could not collect precisely because of some difficulties. Main reasons are reluctance of squatter households and some family members were out of Yangon. Therefore, total squatter population can be over half million. All data related squatters are stored and maintained by digitization with finger print and future steps for easily handling on Screening \& Classification and Countermeasures process.

\subsection{Socio-Economic Condition of Current Squatters}

UN-Habitat (Myanmar) had conducted a survey on informal settlement in Hlinethaya (most populous squatter population) in 2018 (UN-Habitat, 2019). The majority of households are the squatting over 10 years (12\%), between $5-10$ years (37\%) and rests of them are lower than 5 years. Natives are mainly from Ayeyarwady Region (58\%), various regions (9\%) and rests of them from elsewhere from Yangon Region.

Driving factors are identified for migration mainly differentials in earnings, job availability and differences in working conditions and urban lifestyle. Although they have many challenges for migration, enabling factors that can help to overcome the challenges; these include the relative accessibility of transportation to urban jobs, telecommunication technology, and mostly importantly social networks. Social networks strongly serve many purposes such as: identifying job opportunities while in the village of origin; securing accommodation in destination sites; and lowering the psychological burden of moving into an unknown environment (World Bank, 2016).

Over half of the households have moved several times before setting at current location. Most of houses have made as temporary shelter by bamboo, wood, large leaves and water proof canvas. A few less than $10 \%$ were constructed by durable materials as corrugated sheets, bricks and concrete. $72 \%$ of houses are owned, $25 \%$ are rent and 3\% live for free (UN-Habitat, 2019). 
Regarding the educational status, only $2 \%$ have graduated, secondary (37\%), primary $(38 \%)$ and rest of them are informal education or too young to attend school. Most people work in factories (30\%), do casual laboring (16\%), skill construction workers (13\%), small business owners (13\%) and street vendors (10\%) and rest of them are in various small jobs. Occupation of working household members can be seen in Figure 7.

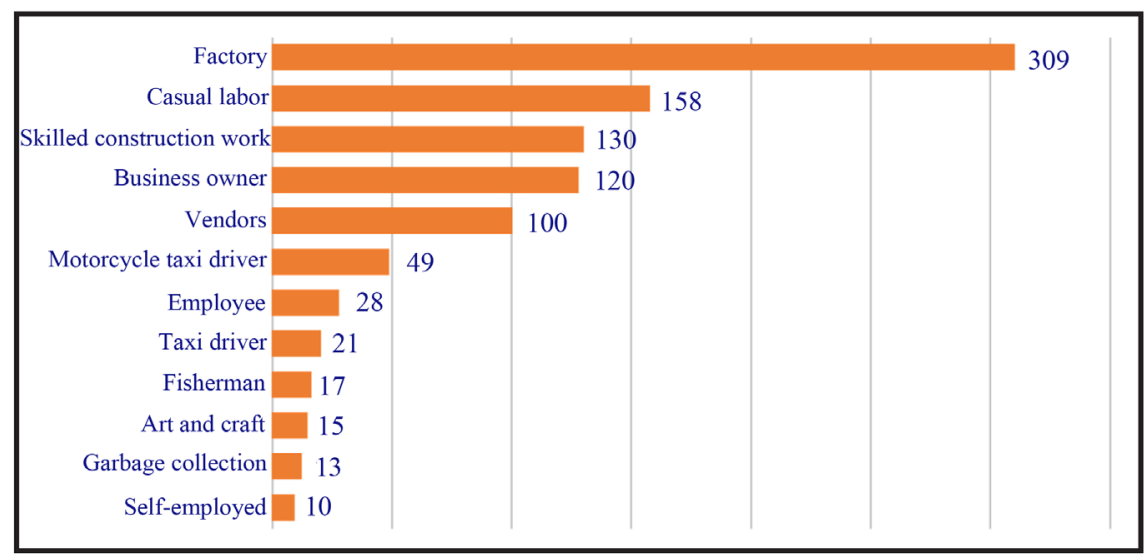

Figure 7. Occupation of working household members from Hlinethaya Township. Source: (UN-Habitat, 2019).

\subsection{Sentiment of Squatter Households}

According to the outcome of FGD, advantages of living in informal settlement are the proximity to the workplace; good business opportunities; good transportation; proximity to relatives, school and markets; and cheap or absence rental fees. Disadvantages are no access to electricity, noisy surrounding, flooding, scarcity of water, bad smells in the surroundings and risk of fire.

According to the survey report by UN-Habitat (Myanmar), majority of households know that their status and living situation is by no means secure and more than half (58\%) understand that they can live in their current spot only as long as the authorities allow them to. Although half of household are willing to move, majority (87\%) have no plans of moving in the next two years with main reasons as poor infrastructures and lack of basic services, lack of job opportunities, and long distance to current jobs and transportation system (UN-Habitat, 2019).

Over half of them (53\%) are reluctant to move to new settlement area by government program. One interesting thing is the willingness to move decrease according to the length of time a household has lived in the area. Therefore, survey recommended seven points to authorities for planning on resettlement of squatter as follows:

1) Consider the length of time that households have been living in the area;

2) Focus on role of woman in decision-making process;

3) Map social networks and assess their importance to relocation;

4) Assess households land rights and ownership;

5) Ensure full transparency of the process; 
6) Cooperate with local employers;

7) Consider the possibility of new informal settlement emerging.

\section{Countermeasures for Current Squatter Formation}

After squatter registration, YRG has been finding and introducing valid countermeasures for current squatter formation. Firstly, YRG has proposed new town project (New Yangon City) in 2018 which is located in South-West part of Greater Yangon. This large-scale project is intended for horizontal extension of Greater Yangon Master Plan as Mega city for 10 million populations in 2040. Other objectives are to create job opportunities with industrial zones and special economic zones, and to settle current squatter population (NYDC, 2019).

Unfortunately, implementation process has been long lasting with many controversial issues especially environmental impacts, requirement of basic infrastructure with huge capital, doubtful outcomes, political arguments, and final approval of the Union Government of Myanmar. Finally, YRG has currently decided and declared four countermeasures to upgrade current slum formation in 2019 as follows:

1) Low-cost public housing delivery by YRG and DUHD

2) Housing finance as housing mortgage with discount interest rate and housing micro finance

3) Community-led Housing (Initiated by Women for the World)

4) PPP program for Dormitory with factory owners in industry zone

Among these countermeasures; community-led housing scheme is the most coverage on the slum population. Low-cost public housing could sell out only about 1000 - 1500 units per annum for low-income group including squatter household. Similarly, housing mortgage cannot extend with many reasons especially high interest rate and high default rate, and unaffordability for urban poor. Likewise, PPP program is very difficult to initiate because of lack of collaboration of factory owners. Therefore, YRG has been promoting Community-led Housing Scheme which is the key countermeasure and extending to large scale with the phase one as 6000 units and phase two as 60,000 units in six new satellite towns.

\subsection{Pilot Projects for Community-Led Housing Scheme}

Women for the World (WfW) ("Pyo Maw Eain" in Myanmar language) is found as NGO in 2004 and initially focus on empowering women and youth to lead process of positive change for transition era of Myanmar. In present, it works to promote women's human right empowerment, livelihood, income generation, food security, community infrastructure, and land \& housing. As its core concept, WfW has positioned itself as a community-based practice and they had introduced community-led housing project as first pilot project in Hlinethaya Township in 2014.

It was initiated by a small saving activity by some women from squatter pock- 
et with the support of Asian Coalition for Community Action (ACCA) by Asian Coalition for Housing Right (ACHR) (ACHR, 2018). This small saving group had tried to purchase formal government land. Finally, they found and informally bought a small piece of agricultural land of 1.338 hectare which is enough for 20 families.

The construction of houses took just three months with a loan of USD 1490 per family (including the cost of land and substandard house). WfW led the project and supported the planning, designing and financial management along with community architects network. However, the central doer was the community. Community-led housing project sample models as cluster design and housing design can be seen in Figure 8.
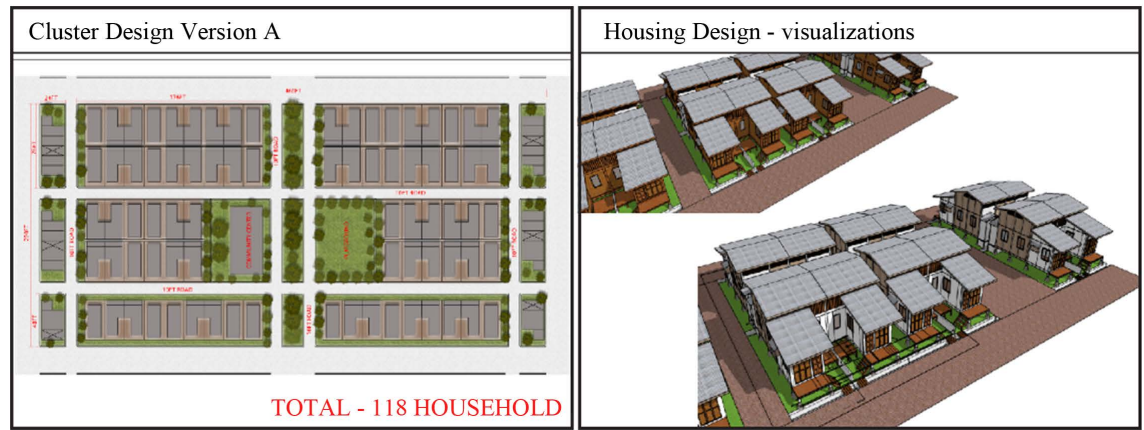

Figure 8. Cluster design and housing design for community-led housing project. Source: (WfW, 2019).

WfW has been trying to extend scale up of this model and there were 8 community-led housing projects and provided shelter for more than 2800 people. The cost of building a single house (including the cost of land) is around 1500 to 2000 USD. Each household has to repay monthly around 20 - 25 USD over a period of 5 - 6 years. This financing scheme is very cheap and affordable for urban poor and which can compare conventional low-cost housing of DUHD as 7000 to 10,000 USD: $30 \%$ down payment: monthly instalment 55 to 85 USD for 15 years period.

\subsection{Practicability of Community-Led Housing Scheme as the Participatory Approach}

The participatory approach is the most applicable practice for slum upgrading in the late $20^{\text {th }}$ Century, which is not exercised on Myanmar until first decade of $21^{\text {st }}$ Century. While participatory approach could produce certain successful outcome according to the experiences in Asia, Botes and Rensburg (2000) argued that some factors can impede the achievement of this approach and symbolized as nine plagues. According to the questionnaire survey result, the majority of respondents agreed that these nine factors can obstruct and fail on implementation of participatory approach in Yangon.

Using the Likert-type scale, the respondents were questioned to rate their 
agreement or disagreement to identify the important failing factor from these nine plagues (a five-point scale as $5=$ totally agree; 4 = agree; $3=$ neutral; $2=$ disagree; 1 = totally disagree). As the result, rate of each nine plagues is over the neutral scale as 3 and smallest result is at least 3.4. Therefore, all respondents accepted that these failure factors can definitely impede when the participatory approach is applied in Yangon.

Among them, respondents pointed to the most important factors as (P-2) The inhibiting and prescriptive role of the state; $(\mathrm{P}-1)$ The paternalistic role of development professionals; (P-4) Selective participation; and (P-8) Excessive pressure for immediate results the accentuation of product at the expense of process, consecutively. Survey results can be stated in detail at Figure 9.

\begin{tabular}{|c|l|c|}
\hline Code & \multicolumn{1}{|c|}{ Failure Factor } & Rate \\
\hline $\mathrm{P}-1$ & The paternalistic role of development professionals & 3.83 \\
\hline $\mathrm{P}-2$ & The inhibiting and prescriptive role of the state & 4.16 \\
\hline $\mathrm{P}-3$ & The over-reporting of development successes & 3.54 \\
\hline $\mathrm{P}-4$ & Selective participation & 3.80 \\
\hline $\mathrm{P}-5$ & Hard-issue bias & 3.45 \\
\hline $\mathrm{P}-6$ & $\begin{array}{l}\text { Conflicting interest group with end-beneficiary } \\
\text { communities }\end{array}$ & 3.45 \\
\hline $\mathrm{P}-7$ & Gate-keeping by local elites & 3.77 \\
\hline $\mathrm{P}-8$ & $\begin{array}{l}\text { Excessive pressure for immediate results the } \\
\text { accentuation of product at the expense of process }\end{array}$ & 3.80 \\
\hline $\mathrm{P}-9$ & The lack of public interest in becoming involved & 3.41 \\
\hline
\end{tabular}

Figure 9. Failure factors of participatory approach in Yangon context. Source: Analyzed from the questionnaire survey results.

Moreover, majority of stakeholders are dubious on the role of government in the new approach because of previous mismanagement under Socialism and Military regime. Therefore, only $26 \%$ of respondents agreed that this approach can be successful in Yangon Context, while the remaining 55\% of respondents tend to favor the uncertainty of the success of participatory approach.

Results of KII points out that pilot projects got partially good results, implementers should focus on how to extend the coverage of the whole city. Furthermore, they must try to uplift not only housing and physical infrastructures but also socio-economic status of urban poor community as Indonesia model for cutting vicious urban poverty cycle. Moreover, policy makers should consider all alternative countermeasures which are applicable to Yangon context such as site and services scheme, on-site slum upgrading, rental housing either public or private sector which should be polished up with the fundamentals from LAC region experiences.

\section{Conclusion and Recommendations}

Although resettlement schemes with force eviction were mainly applied in previous slum formations especially the second formation (1950s) and the third formation (1990s) because of dictatorships, YRG cannot exercise on eviction practice because of current democratization. With the introduction of participatory approach as community-led housing scheme; newest countermeasure, which 
may be applicable for Yangon context, majority of stakeholders doubt its practicability. Specific concerns are about the mind-set of government and governmental organizations such as short-lived enthusiasm of government will and inapplicable bureaucratic rules and regulations. On the other hand, lawlessness manner of squatters in public can harm the effort of YRG.

Although the tools of community-led housing projects in Myanmar are generally in line with "Do" and "Don't" list of UN guidelines, these cannot drive to promote good urban governance systems, to implement and monitor pro-poor growth, and to combine slum upgrading with employment generation and local economic development.

Therefore, policy makers should not consider slum upgrading solely as a social issue which is the "Don't" list of UN recommendation. Pilot projects have obtained partially good results; implementers should focus on how to extend the coverage to the whole city. Furthermore, they must try to uplift not only housing and physical infrastructures but also socio-economic status of urban poor communities as Indonesia have done in cutting vicious urban poverty cycle.

Current squatter formation is at least two-fold of previous formations and it cannot easily solve in medium-term like as previous countermeasures. Therefore, union and region government should have strong will as Sri Lanka and officially set up long-term policy and strategic plans coordinated with the Myanmar Sustainable Development Plan. Moreover, the study recommended that government should form a particular organization (such as CODI from Thailand experience) which is the leading role for squatter upgrading toward sustainable development. This paper focuses only on the hard infrastructures of implementation and further researches should be recommended on soft infrastructures related slum and squatter especially institutional strengthening and improvement of legal framework.

\section{Conflicts of Interest}

The authors declare no conflicts of interest regarding the publication of this paper.

\section{References}

Abu-Salia, R., Osumanu, I. K., \& Ahmed, A. (2015). Coping with the Challenges of Urbanization in Low Income Areas: An Analysis of the Livelihood Systems of Slum Dwellers of the Wa Municipality, Ghana. Current Urban Studies, 3, 105-118. https://doi.org/10.4236/cus.2015.32010

ACHR (2018). Ground Development: Reflections on Community-Based Practices in Sri-Lanka and Myanmar.

Andavarapu, D., \& Edelman, D. J. (2013). Evolution of Slum Redevelopment Policy. Current Urban Studies, 1, 185-192. https://doi.org/10.4236/cus.2013.14021

APMCHUD (2010). Background Paper for Working Group 2: Participatory Slum Upgrading. In 3rd Meeting of Asia Pacific Ministerial Conference on Housing and Urban Development (pp. 1-8). 
Archer, D. (2012). Baan Mankong Participatory Slum Upgrading in Bangkok, Thailand: Community Perceptions of Outcomes and Security of Tenure. Habitat International, 36, 178-184. https://doi.org/10.1016/j.habitatint.2011.08.006

Botes, L., \& Van Rensburg, D. (2000). Community Participation in Development: Nine Plagues and Twelve Commandments. Community Development Journal, 35, 41-58. https://doi.org/10.1093/cdj/35.1.41

Croese, S., Cirolia, L. R., \& Graham, N. (2016). Toward Habitat III: Confronting the Disjuncture between Global Policy and Local Practice on Africa's "Challenge of Slums". Habitat International, 53, 237-242. https://doi.org/10.1016/j.habitatint.2015.11.037

CSO (2015). Statistical Yearbook 2015. Nay Pyi Taw: Ministry of Finance and Planning.

Das, A. (2015). Autonomous But Constrained: CBOs an Urban Upgrading in Indonesia. Cities, 48, 8-20. https://doi.org/10.1016/j.cities.2015.05.009

Dhabhalabutr, K. (2016). The Empowerment of the Slum Inhabitant as a Primary Agent of Low-Income Housing: Slum Upgrading in Thailand between 1980 and 2011. Procedia-Social and Behavioral Sciences, 216, 428-439.

https://doi.org/10.1016/j.sbspro.2015.12.057

DoP (2015). The 2014 Myanmar Population and Housing Census. Nay Pyi Taw: Department of Population.

DoP (2016). Thematic Report on Migration and Urbanization. Nay Pyi Taw: Department of Population.

GAD (1982). History of Rangoon Municipality. Rangoon: Department of General Administration.

Gilbert, A. (2007). The Return of the Slum: Does Language Matter? International Journal of Urban and Regional Research, 31, 697-713.

https://doi.org/10.1111/j.1468-2427.2007.00754.x

HD (1987). Report of the 25 Years Activities by Housing Department (1962-1987). Rangoon: Housing Department.

HLPF (High-Level Political Forum, United Nation) (2018). 2018 Reviews of SDGs Implementation: SDG 11-Make Cities and Human Settlements Inclusive, Safe, Resilient and Sustainable.

Johar, N. (2017). Community Participation: A Cementing Process, Theorizing Various Dimensions and Approaches. Journal of Construction in Developing Countries, 22, 47-61. https://doi.org/10.21315/jcdc2017.22.supp1.3

Joshi, S., \& Khan, M. S. (2010). Aided Self-Help: The Million Houses Programme-Revisiting the Issues. Habitat International, 34, 306-314.

https://doi.org/10.1016/j.habitatint.2009.11.010

Kyaing, K. (2014). Urban Land Use Pattern and Residential Land in Yangon. Yangon: Yangon Institute of Economics.

Kyaw, K. M. (1971). Myanmar Naing Ngan Thar Myar Hnaint Naing Ngan Gya Thar Myar Pyat Tha Nar (Problem between Myanmar Nationalities and Foreigners in Myanmar). Yangon: Hla Myo Press.

Magalhaes, F. (2016). Slum Upgrading and Housing in Latin America. New York: Inter-American Development Bank. https://doi.org/10.18235/0000402

Majale, M. (2008). Employment Creation through Participatory Urban Planning and Slum Upgrading: The Case of Kitale, Kenya. Habitat International, 32, 270-282. https://doi.org/10.1016/j.habitatint.2007.08.005 
Malik, S., Roosli, R., \& Tariq, F. (2020). Investigation of Informal Housing Challenges and Issues: Experiences from Slum and Squatter of Lahore. Journal of Housing and the Build Environment, 35, 143-170. https://doi.org/10.1007/s10901-019-09669-9

Maung, T. (1963). Yangon Yazawin Thamine (A History of Rangoon) (Myanmar Language). Rangoon: Zwe Press.

Menshawy, A. E., Shafik, S., \& Khedr, F. (2016). Affordable Housing as a Method for Informal Settlements Sustainable Upgrading. Procedia-Social and Behavioral Sciences, 223, 126-133. https://doi.org/10.1016/j.sbspro.2016.05.330

Meredith, T., \& MaCdonald, M. (2017). Community-Supported Slum-Upgrading: Innovations from Kibera, Nairobi, Kenya. Habitat International, 60, 1-9. https://doi.org/10.1016/j.habitatint.2016.12.003

Minnery, J., Argo, T., Winarso, H., Hau, D., Veneracion, C. C., Forbes, D., \& Childs, I. (2013). Slum Upgrading and Urban Governance: Case Studies in Three South East Asian Cities. Habitat International, 39, 162-169. https://doi.org/10.1016/j.habitatint.2012.12.002

Moe, S. T. N. (2013). Report of the Hut to Apartment Schemes under DHSHD. Yangon: Department of Human Settlement and Housing Development.

Nazire, H., Kita, M., Okyere, S. A., \& Matsubara, S. (2016). Effects of Informal Settlement Upgrading in Kabul City, Afghanistan: A Case Study of Afshar Area. Current Urban Studies, 4, 476-494. https://doi.org/10.4236/cus.2016.44031

NYDC (2019). New Yangon City: Final Master Plan Report. Yangon: New Yangon Development Company (NYDC).

Ooi, G. L., \& Phua, K. H. (2007). Urbanization and Slum Formation. Journal of Urban Health, 84, 27-34. https://doi.org/10.1007/s11524-007-9167-5

RDT (1941). Report of the Rangoon Development Trust Enquiry Committee. Rangoon: Government Printing and Stationery.

Tudawe, I. (2001). Chronic Poverty and Development Policy in Sri Lanka: Overview Study. CPRC Working Paper No. 9, Manchester: Chronic Poverty Research Center.

Tunas, D., \& Peresthu, A. (2010). The Self-Help Housing in Indonesia: The Only Option for the Poor? Habitat International, 34, 315-322.

https://doi.org/10.1016/j.habitatint.2009.11.007

UN-Habitat (2003). Global Report on Human Settlements: The Challenge of Slums. Nairobi: UN-Habitat.

UN-Habitat, Myanmar (2018). Yangon Informal Settlement-Resettlement Programme (YISRP). Yangon: UN-Habitat, Myanmar.

UN-Habitat, Myanmar (2019). Informal Settlement Survey Report. Nay Pyi Taw: UN-Habitat Myanmar.

Van Horen, B. (2004). Community Upgrading and Institutional Capacity Building to Benefit the Urban Poor in Asia. Forum on Urban Infrastructure and Public Service Delivery for the Urban Poor Regional Focus: Asia. New Delhi: India Habitat Centre.

WfW (2019). Report for Mid-Project Review, Women for the World. Yangon.

World Bank (2016). A Country on the Move: Domestic Migration in Two Regions of Myanmar. Nay Pyi Taw: World Bank Group.

YRG (2017). Report on Squatter Registration Project. Yangon: Yangon Region Government. 